28 Research Square

\title{
Udder, teat and milk vein morphology of Indian dromedary camel and its relationship with milkability traits
}

\author{
Manoj Kumar \\ College of Veterinary and Animal Science Bikaner \\ Manju Nehara \\ College of Veterinary and Animal Science Bikaner \\ ved Prakash ( $\square$ ved.prakash4@icar.gov.in ) \\ National Research Centre on Camel \\ Urmila Pannu \\ College of Veterinary and Animal Science Bikaner \\ Basanti Jyotsana \\ National Research Centre on Camel
}

\section{Research Article}

Keywords: Dromedary camel, Teat, Udder, Milkability, Milk yield, Correlation

Posted Date: February 15th, 2022

DOI: https://doi.org/10.21203/rs.3.rs-1315604/v1

License: (9) (1) This work is licensed under a Creative Commons Attribution 4.0 International License. Read Full License 


\section{Abstract}

The economic viability of the camel in the current scenario can be ensured by improving its dairy potential. The study on the udder and teat characteristics of dromedary and its relationship with milk yield and milkability can be of great value in establishing camel as a dairy animal. The present study was conducted on 45 lactating she-camels of four Indian camel breeds viz. Bikaneri, Jaisalmeri,Kachchhi and Mewari stationed at ICAR-NRCC Bikaner, Rajasthan (India). Various udder and teat morphology, milk yield and milkability traits, factors affecting these traits and the relationship between these traits were studied in hand-milked Indian dromedary camel. The means \pm S.E. of teat lengths of left fore, left rear, right fore and right rear teats were measured as $52.21 \pm 1.66,58.52 \pm 2.11,50.13 \pm 1.74$ and $54.37 \pm 1.82 \mathrm{~mm}$, respectively. The means $\pm \mathrm{S}$.E. of teat diameters for left fore, left rear, right fore and right rear teats were $42.44 \pm 1.60,46.01 \pm 1.68,39.29 \pm 1.31$ and $45.20 \pm 1.56 \mathrm{~mm}$, respectively. The means \pm S.E for udder depth, udder length, udder height from the ground, milk vein diameter and milk vein length were observed as $25.44 \pm 0.42,37.29 \pm 0.80,114.80 \pm 0.80,2.02 \pm 0.08$ and $88.70 \pm$ $0.96 \mathrm{~cm}$, respectively. The effect of age at calving was significant $(p \leq 0.05)$. Positive and highly significant $(p \leq 0.01)$ correlations of milk yield were observed with the majority of udder and teat characteristics, milking time, milk flow rate while a negative correlation was found with udder height and milk let down time. It can be concluded that udder characteristics are influenced by various genetic and non-genetic factors and its relationship with milk yield and milkability can be used for selection and dairy management purposes.

\section{Introduction}

The camel (Camelus dromedarius) is a significant component of Indian desert ecosystem. It survives under the conditions of water and feed scarcity and thrives well on the available bushes, shrubs and trees. Nowadays the camel milk is gaining importance because of its therapeutic properties in many diseases. It has been proven that it contains a group of natural elements and compounds which have the special therapeutic ability in diseases such as diabetes, diarrhoea, food allergies, autism, cancer, chronic hepatitis and cardiovascular diseases (Hammam, 2019). Camel milk has been the major source of nourishment for camel pastoralists since years. The decreased utility of camel as a draught animal also resulted in exploration of its dairy potential. Camel milk dairies have come up as business activity in most camel possessing nations and the market potential for camel milk could be highly developed in the future (Faye et al. 2014).

For developing camel as a dairy animal, evaluation for different aspect of milk production like milk yield, udder and teat characteristics and milkability is imperative. Udder morphology traits determine several aspects of milkability so these traits should be considered as economically important traits for improving camel herds (Ayadi et al. 2016). Inclusion of udder characteristics in breeding programs of dairy camel, beside milk quality and production traits has been suggested by (Mussad et al. 2017). External udder measurements can give us an idea about the storage capacity of the udder and that could be used as additional parameters. According to (Eisa et al.2010) the camel udder morphometric traits have an impact on milk yield and indicate themilk secretion potential. The udder morphology has positive genetic response in the milkability of dairy camel (Ayadi et al. 2013). Milkability is an important functional trait with great influence on the production costs in dairy. Monitoring the milkability of animals allows to improve efficiency of milking procedures and reduce farm production costs (Rensing, 2005). However, information on udder characteristics for Indian camel and its relationship with milkability has not been reported. Hence, present study was planned to study udder and teat characteristics of hand milked Indian dromedary camel, factors affecting them and its relationship with milkability traits.

\section{Materials And Methods}

\section{Animals and management}

The study was conducted on 45 lactating she camels of four breeds viz. Bikaneri (16), Jaisalmeri (8), Kachchhi (15) and Mewari (6) calved during the year 2020 at ICAR-NRCC, Bikaner. The geographical location is $28.3^{0} \mathrm{~N}$ and $73.5^{\circ} \mathrm{E}$ with mean annual rainfall of $277.55 \mathrm{~mm}$. The temperatures range between $30^{\circ} \mathrm{C}$ to $45^{\circ} \mathrm{C}$ in summer and $4^{\circ} \mathrm{C}$ to $28^{\circ} \mathrm{C}$ in winter. The region is characterized by semi-arid, sandy and harsh with extreme adverse climatic conditions. All the animals under study experienced similar environmental conditions of temperature and humidity. The lactating she camels were reared under semiintensive system of management. The details of feeding, grazing and milking management followed at farm has been reported by Prakash et al. (2022).

\section{Udder Teat, and milk vein morphology traits}

The teat, udder and milk vein morphology were recorded by digital vernier calliper and measuring tape. The measurements were recorded immediately after "let-down" of milk and just before start of milking. The teat and milk vein diameters were measured using digital vernier callipers (Divinext Aerospace Digimatic calliper 0-150 mm, India). The length, depth and height measurements were taken using measuring tape.

Teat length and diameter $(\mathrm{mm})$ : The teat length was measured as distance from teat insertion base to the teat orifice (Fig. 1). The diameter of the teat was measured at the middle portion (Fig.2) by the method described by Abdalla et al. (2015) The teat length and diameter was measured for:(a) Left Fore (LF) (b) Left Rear (LR) (c) Right Fore (RF) (d) Right Rear (RR) teats.

Udder Length $(\mathbf{c m})$ : The udder length was measured from rear attachment to fore attachment of udder along the median line passing between the two halves of the udder (Fig.3).

Udder depth (cm): The distance was measured from the rear attachment of udder with abdominal wall to the base of teat (Fig.4).

Udder height from ground (cm): It was taken as distance from ground to the base of the teat (Fig.5). 
Milk vein length $(\mathbf{c m})$ : The linear length of the milk vein was recorded by measuring the linear distance in straight line covered by the milk vein visible in front of the fore quarters up to the milk well where the vein entered into the abdomen (Fig.6).

Milk vein diameter (mm): -The milk vein diameter (Fig.7)was taken by the method described by Abdalla et al. (2015).

\section{Milkability Traits}

The milkability traits were recorded as milk yield (kg), milk let-down time(s), milking time (min) and milk flow rate (kg/min) during morning milking.

Milk yield : The calves were allowed to suckle their dams to stimulate milk secretion, until the milk started to flow and then the calf was separated. The milking was done in standing position (Fig.8). The milk yield was recorded with a digital weighing balance.

Milk let-down time (MLDT): It was calculated from the time of allowing the calf to suckle to separation of the calf from suckling.lt was recorded with the help of a stopwatch.

Milking time (MT): It was calculated as time taken by the milkers from start of milking to completion of milking. It was recorded with the help of astopwatch.

Milk flow rate (MFR): It was calculated as milk yield per milking $(\mathrm{kg}) /$ total milking time $(\mathrm{min})$

\section{Statistical analysis}

\section{Descriptive statistics}

The descriptive measures (Mean, SE, SD, Range and CV value)of udder, teat and milk vein measurements, milk yield and milkability parameters was calculated using SPSS ver.26.0.

\section{Factors affecting udder, teat and milk vein morphology traits}

In order to study the effect of various factors affecting teat and udder morphology traits a linear fix model was used. Age at calving was taken as a covariable. The data was analysed using the General Linear Model (GLM) procedure of SPSS ver. 26.0.

$Y_{i j k}=\mu+A_{i}+B_{j}+b C_{k}+e_{i j k}$

Where, $\mathrm{Y}_{\mathrm{ijk}}=$ Individual teat and udder and milk vein measurement, $\mu=$ Overall population mean, $A_{i}=$ Fix effect of breed, $B_{j}=$ Fix effect of parity, $b=$ Linear regression coefficient of age at calving $\left(C_{k}\right)$ on udder, teat and milk vein measurements, $e_{i j k}=$ Random error associated with each observation, NID $\left(0, \sigma^{2}\right)$

\section{Correlation analysis}

To determine the degree of relationship between milkability traits and udder, teat and milk vein morphology traits product moment correlation ( $r$ ) was calculated. Pearson correlation analysis was performed by correlate procedure of SPSS ver.26.0.

\section{Results And Discussion}

\section{Descriptive Statistics}

\section{Teat length}

The means \pm S.E. of teat lengths of left fore, left rear, right fore and right rear teat were $52.21 \pm 1.66,58.52 \pm 2.11,50.13 \pm 1.74 \mathrm{and} 54.37 \pm 1.82 \mathrm{~mm}$, respectively (Table1). The observed length of left rear teat and right fore teat was highest and lowest, respectively in Indian dromedary camel. The results of present study was fairly in agreement with (Ayadi et al. 2013; Abdalla et al. 2015; Atigui et al. 2016) in dromedary camel, they also reported that rear teats were longer than fore teats. The range of teat length recorded in the current study was in close agreement with results of (Musaad et al. 2017; Kaskous, 2018) in dromedary camel.

\section{Teat diameter}

The mean left fore, left rear, right fore and right rear teat diameter were $42.44 \pm 1.60,46.01 \pm 1.68,39.29 \pm 1.31$ and $45.20 \pm 1.56 \mathrm{~mm}$, respectively (Table 1). The diameter of left rear teat was found highest and right fore teat was found lowest in Indian dromedary camel. It was also observed that teat lengths and teat diameters were slightly higher for rear teats as compared to fore teats. Similar range of teat diameter was also observed by Musaad et al. (2017) which ranged from $2.94 \pm 0.18$ to $4.01 \pm 0.45 \mathrm{~cm}$ in dromedary camel.

\section{Udder morphology traits}

The means \pm S.E. for udder depth, udder length and udder height from ground were observed as $25.44 \pm 0.42,37.29 \pm 0.80$ and $114.80 \pm 0.80 \mathrm{~cm}$, respectively (Table 1). The udder depth in the current study was similar to udder depth measurements of $26.00 \pm 0.75 \mathrm{~cm}$ reported by Atigui et al. (2016), $25.00 \pm 0.48 \mathrm{~cm}$ reported by Kaskous (2018) in dromedary camels. However, lower value for udder depth (16.90 $\pm 2.5 \mathrm{~cm})$ was reported by Eisa et al. 
(2010) in Arabi-Lahwee camels. Higher values of $(44.50 \pm 0.64 \mathrm{~cm})$ by Ayadi et al. (2013); $(40.14 \pm 0.66 \mathrm{~cm})$ by Musaad et al. (2017); (47.91 \pm 0.50$) \mathrm{cm}$ by Ayadi et al. (2016) were also reported in dromedary camel. Similar, to current study the udder length measurement of (38.60 $\pm 0.44 \mathrm{~cm})$ was reported by Ayadi et al. (2016) in dromedary camels. However, lower values $(25.60 \mathrm{~cm})$ were observed by Kaskous(2018) in dromedary camels. The higher values were also reported by Ayadi et al. (2013) as $49.68 \pm 0.90 \mathrm{~cm}$ and Musaad et al. (2017) as $42.05 \pm 0.97 \mathrm{~cm}$ in dromedary camels. The results for udder height from ground (UHG) were found higher than the UHG measurements of $110 \pm 7.6 \mathrm{~cm}$ by Eisa et al. (2010), (107.48 $\pm 1.44 \mathrm{~cm})$ by Ayadi et al. (2013), (111.0 \pm $7.1 \mathrm{~cm}$ ) by Kaskous (2018) in dromedary camels.

\section{Milk vein morphology traits}

Mean \pm S.E. for milk vein diameter and milk vein length were measured as $2.02 \pm 0.08 \mathrm{~cm}$ and $88.70 \pm 0.96 \mathrm{~cm}$, respectively (Table 2 ). Slightly higher milk vein diameter $(2.31 \pm 0.09) \mathrm{cm}$ was observed by Ayadi et al. (2013) in dromedary camels. However, lower milk vein diameter $(1.80 \pm 0.5 \mathrm{~cm})$ but similar milk vein length $(88.0 \pm 7.7 \mathrm{~cm}$ ) was observed by Eisa et al. (2010) in Arabi-Lahwee camels. The differences in udder teat and milk vein morphology may be due to differences in camel type (individuality), breed, parity and lactation stage.

\section{Milkability traits}

The descriptive statistics for milk yield and milkability traits are described in (Table-1). The mean morning milk yield, milk let-down time, milking time and milk flow rates was $2.18 \pm 0.10 \mathrm{~kg}, 57.15 \mathrm{~s}, 1.78 \mathrm{~min}$ and $1.23 \mathrm{~kg} / \mathrm{min}$, respectively. Faraz et al. (2018) reported higher morning milk yield (3.16 $\pm 0.15 \mathrm{~kg}$ ) in Marecha she-camel. The let-down time varying from $36.0 \pm 6.9$ to $126.9 \pm 41.1$ s were reported by (Wernery et al. 2004; Hammadi et al. 2010; Bekele et al. 2011) in camel. The milking time ranging from 98.6 s to 4.8 min has been reported in camels by (Hamamdi et al. 2010; Bekele et al.2011). Similar, milk flow rate of $1.23 \mathrm{~kg} / \mathrm{min}$. by Prakash et al. (2022) and lower milk flow rate of $1.11 \mathrm{~kg} / \mathrm{min}$ by Abdelgadir (2018) was reported in dromedary camel. The milk let-down time depends on degree of udder filling which is affected by factors such as interval between milking, breeds, stage of lactation and udder cistern volume.

\section{Factors affecting teat morphology traits}

The effect of breed, parity and age at calving were studied (Table 2) on teat lengths and teat diameter. The effect of breed was found significant ( $\mathrm{p} \leq 0.05$ ) on the lengths of left fore and right fore teats. However, the effect of breed was found non-significant on the lengths of left rear and right rear teats. Effect of breed was found non-significant for all the teat diameters except right rear teat (Table 2). Teat length measurements were higher in Kachchhi and Mewari breeds compared to Jaisalmeri and Bikaneri breeds (Table 2). This finding was in agreement with the reports of (Juhasz and Nagy, 2008; Eisa et al. 2010; Kaskous 2018), they also observed variation in the teat length and diameter in different camel breeds. However, Abdallah and Faye (2012) and Ayadi et al. (2013) found that teat length showed similar measurements in different breeds of camel in Saudi Arabia.

The effect of parity was found non-significant on all teat length and teat diameter measurements (Table 2) except right rear teat diameter(p $\leq 0.05$ ). However, Mostafa et al. (2018) reported that the teat measurements showed significant $(p \leq 0.05)$ increment with advancing parity in lactating Maghrebi camel. The effect of age at calving on teat lengths was inconsistent. It had highly significant $(p \leq 0.01)$ effect on left fore teat, significant $(p \leq 0.05)$ effect on left rear and right fore teats while non-significant effect on right rear teat length (Table2). The effect of age at calving on teat diameters were found non-significant except significant $(p \leq 0.05)$ effect on left fore teat (Table 2). Vyas et al. (2019) also reported that the effect of age of she camels did not affect the teat measurements significantly except right front tip of teat.

\section{Factors affecting udder and milk vein morphology traits}

The effect of breeds, parity and age at calving on udder and milk vein morphology is given in (Table 3). Effect of breed and parity was non-significant for all udder and milk vein morphology traits. Interaction between breed and parity was also found non-significant. In contrast to our study, Mostafa et al. (2018) reported that the udder measurements significantly $(p \leq 0.05)$ increased by advancing parity in lactating Maghrebi camel. The effect of age at calving was highly significant $(p \leq 0.01)$ on milk vein diameter, significant $(p \leq 0.05)$ on udder depth and udder length. While the effect of age at calving was found non-significant on milk vein length and udder height from ground. The differences in udder and milk vein morphology may be due to differences in camel type (individuality), breed, parity and lactation stage.

\section{Phenotypic correlations among udder, teat and milk vein morphology traits}

The phenotypic correlations among udder, teat and milk vein morphology traits are presented in (Table 4). The phenotypic correlation among all four teat lengths were very positive, highly significant $(\mathrm{p} \leq 0.01)$ and high in magnitude. It ranged from 0.765 (RR-RF) to 0.907 (RR-LR). The phenotypic correlation among teat diameters were also positive, highly significant $(\mathrm{p} \leq 0.01)$ and high in magnitude and ranged from 0.663 (RF-LF) to 0.841 (LR-RR). The phenotypic correlation of all teat lengths with all teat diameter measurements were positive (Table 4). and highly significant ( $\mathrm{p} \leq 0.01)$ which ranged from 0.421 (TL-RR and TD-RF) to 0.850 (TL-LF and TD-LF). A positive correlation between teat length and teat diameter was also reported by Prakash et al. (2022) in dromedary camel.

The positive and highly significant correlation ( $r=0.686, p \leq 0.01)$ was observed between udder length and udder depth (Table 4). Ayadi et al. (2016) also reported that udder depth and udder length are positively correlated $(r=0.72)$ in dairy camels. However, udder height from ground had negative correlation with teat length, teat diameter, udder depth, udder length and milk vein measurements. Positive and highly significant correlation ( $\mathrm{p} \leq 0.01$ ) was observed for udder depth and udder length with all teat lengths and teat diameters (Table4). The positive correlation among udder and teat measurements were also 
observed by Musaad et al. (2017) in the camel. Milk vein diameter and milk vein length had positive and highly significant correlation ( $\mathrm{p} \leq 0.01$ ) with teat length, teat diameters, udder depth and udder length but negative and non-significant correlation with udder height from ground (Table 4).

Thus, positive and highly significant $(\mathrm{p} \leq 0.01)$ correlation exists among udder, teat and milk vein traits except udder height from ground. Correlation findings indicated that as the teat length increases, teat diameters also have a corresponding increase. The negative relationship of udder height from ground with udder, teat and milk vein measurements indicated that animals with the higher udder height from ground has smaller udder and teat size as well as milk vein measurements. Similar, type of phenotypic correlation among different udder and teat traits maybe due to involvement of some common genes governing these traits. It can be suggested that inclusion of only single udder morphology trait will be enough for inclusion in the dairy camel selection schemes.

\section{Relationship between milkability, udder, teat and milk vein morphology traits}

Positive and highly significant $(\mathrm{p} \leq 0.01)$ correlation was observed between milk yield, milking time, milk flow rate, udder depth, udder length, teat lengths, teat diameters, milk vein diameter and milk vein length (Table 5). However, the udder height and milk let-down time was found to be negatively correlated with milk yield, milking time and milk flow rate (Table 5). Ayadi et al. (2013) also reported significant positive correlation of milk yield with udder depth ( $r=$ 0.37), milk vein diameter $(r=0.28)$, milking time $(r=0.61)$, whereas a negative correlation with udder height from ground ( $r=-0.26)$ in dromedary camels. Eisa et al. (2010) also reported positive correlation of milk yield with udder depth, udder length, teat length and teat diameter and negative and nonsignificant correlation with the udder height in Lahween camel. Musaad et al. (2017) also reported that milk yield had positive and significant correlation with udder depth and rear teat length. The study of Prakash et al. (2022) also reported negative association between milk yield and milk let-down time in dromedary camel. Gajbhiye et al. (2007) and Kshatriya et al. (2009) also concluded that biometry of udder was related to milk yield and therefore could be considered as one of the criteria for selection of dairy camels.

Results of present study showed that dromedary camels have well developed udder and milk vein with medium size teats. The correlation study indicated that with the increase in milk yield, total milking time and milk flow rate also increased but milk let-down time decreased. It also indicated that lengthy and deep udders with thicker and longer teats have higher milk yield which may be due to the fact that deep and lengthy udder have more storage capacity of milk. Thus, she-camel with well-developed udder, teat and milk vein are high milk yielders with good milk flow rate and lower milk let-down time. Thus, findings of the study delineate that the udder characteristics can be effectively used as a reliable criterion for selecting camel of good dairy potential as majority of teat, udder and milk vein morphology traits have significant correlation with milk yield. Udder characteristics need to be included in breeding programs and selection scheme of dairy camel along with milk production traits.

\section{Declarations}

\section{Acknowledgments}

Authors deeply acknowledges the contribution and support of staff of Camel Dairy Unit ICAR-NRCC Bikaner for data recording and Director, ICAR- NRCC, Bikaner and Dean, CVAS, Bikaner for granting permission for research work and providing facilities for successful execution of the project.

Funding- Authors deeply acknowledges Director, ICAR- National Research Centre on Camel, Bikaner and Dean, College of Veterinary and Animal Science, Bikaner for providing the funds for successful execution of the project.

Competing interests-The authors declare no competing interests.

Ethics approval - Not Applicable

Consent to participate- Not applicable

Consent for publication- Not applicable

Data Availability -Available upon request from the corresponding author.

Code availability- Not applicable.

Authors contributions - All authors contributed to the study conception and design. Data collection was done by Manoj Kumar. Data analysis was performed by Ved Prakash and Manoj Kumar. The first draft of the manuscript was written by Manoj Kumar and Manju Nehara. The work was supervised by Ved Prakash and Manju Nehara. The editing and proof reading was done by Urmila Pannu and Basanti Jyotsana. All authors read and approved the final manuscript.

\section{References}

1. Abdalla, E.B., Ashmawy, M.H., Farouk, O.A., Salama, F.A., Khalil, and Seioudy, A.F., 2015. Milk production potential in Maghrebi she-camels. Small Ruminant Research, 123, 129-135.

2. Abdallah, H.R., Faye, B., 2012. Phenotypic classification of Saudi Arabian camel (Camelus dromedaries) by their body measurements. Emirates Journal of Food and Agriculture, 24 (3), 272-280. 
3. Abdelgadir, M.M., 2018. Measurements of milk flow and udder morphology and their impact on milkability and selecting of dairy camel's (Camelus dromedarius) under Intensive System. (PhD thesis University of Science and Technology College of Graduate Studies Sudan).

4. Atigui, M., Marnet, P.G., Harrabi, H., Bessalah, S., Khorchani, T. and Hammadi, M., 2016. Relationship between external and internal udder and teat measurements of machine milked dromedary camels. Tropical Animal Health and Production, 48(5), 935 -942.

5. Ayadi, M., Aljumaah, R. S., Musaad, A., Samara, E. M., Abelrahman, M. M., Alshaikh, M. A. and Faye, B., 2013. Relationship between udder morphology traits, alveolar and cisternal milk compartments and machine milking performances of dairy camels (Camelus dromedarius). Spanish Journal of Agricultural Research,11(3),790-797.

6. Ayadi, M., Aljumaah, R. S., Samara, E. M., Faye, B. and Caja, G. 2016. A proposal of linear assessment scheme for the udder of dairy camels (Camelus dromedarius). Tropical Animal Health and Production, 48(5), 927-933.

7. Bekele, T., Lundeheim, N., Dahlborn, K., 2011. Milk production and feeding behavior in the camel (Camelus dromedarius) during 4 watering regimens. Journal of Dairy Science, 94, 1310-1317.

8. Eisa, M.O., Ishag, I.A. and Abu-Nikhaila, A.M., 2010. A note on the relationships between udder morphometric and milk yield of Lahween camel (Camelus dromedarius). Livestock Research for Rural Development, 22 Article \#188. Retrieved from http://www.lrrd.org//rrd22/10/eisa22188.htm

9. Faraz, A., Waheed, A., Nazir, M.M. and Mirza, R.H., 2018. Milk production potential of Marecha dromedary camel in desert Thal Punjab, Pakistan. Journal of Fisheries \& Livestock Production, 6, 280. DOI: 10.4172/2332-2608.1000280

10. Faye, B., Madani, H. and El-Rouili, S. A., 2014. Camel milk value chain in Northern Saudi Arabia. Emirates Journal of Food and Agriculture, 26(4), 359-365 .

11. Gajbhiye, A.R., Wanjari, B.V., Chavan, M.S., Jadhao, S.G. and Sahare, T. Y., 2007. Udder measurements and its correlation with milk productivity in crossbred cattle. Indian Journal of Field Veterinarians, 3(1), 39--40.

12. Hammadi, M., Atigui, M., Ayadi, M., Barmat, A., Belgacem, A., Khaldi, G., Khorchani, T., 2010. Training period and short time effects of machine milking on milk yield and milk composition in Tunisian Maghrebi camels (Camelus dromedaries L.). Journal of Camel Practice and Research, 17, 1-7.

13. Hammam, A. R., 2019. Compositional and therapeutic properties of camel milk. Emirates Journal of Food and Agriculture, 148-152.

14. Juhasz, J. and Nagy, P., 2008. Challenges in the development of a large-scale milking system for dromedary camels. In: P. Nagy, G. Huszenicza, and J. Juhasz, (Eds.) WBC/ICAR 2008 Satellite Meeting on Camelid Reproduction, 12-13 July. Budapest, Hungary. pp. 84-87.

15. Kaskous, S., 2018. Udder morphology and machine milking ability in dromedary camels. International Journal of Agriculture Research Science, 5 (2), 2348-3997.

16. Kshatriya, P.S., Trivedi, M.M. and Dhami, A.J., 2009. Association of udder biometry and skin thickness with milk yield in Kankrej and crossbred cows. Indian Journal of Field Veterinarians, 5(1), 11-13.

17. Mostafa, T.H., El-Malky, O.M., Abd El-Salaam, A.M. and Nabih, A.M., 2018. Milk production and composition in Maghrebi she-camel under different management system in Egypt. IOSR Journal of Agriculture and Veterinary Science, 11, 29-37.

18. Musaad, A., Ayadi, M., Khalil, A., Aljumaah, R.S. and Faye, B., 2017. Udder and teat shape and the relationship with milk yield in camels (Camelus dromedarius). Scholars Journal of Agriculture and Veterinary Sciences, 4(10), 418-423.

19. Prakash, V., Jyotsana, B., Vyas, S., Sawal, R.K., 2022. Study of milkability and associated factors in hand milked Indian Dromedary Camel. Small Ruminant Research, 106600.

20. Rensing, S., 2005. New ways of data recording and genetic evaluation for functional traits. The 26th European Holstein and Red Holstein Conference, Prague, Czech Republic 1-3. Session 2, Available online at: http://www.euholsteins.com/info/con ferences/ehc2005/rensingnewways_functionaltraits_prag20050518.pdf.

21. Vyas, S., Ansari, M.M., Prakash, V., Sharma, N., Kashinath, Patil, N.V., 2019. Teat characteristics of Indian dromedary camel (Camelus dromedarius). Journal of Camel Practice and Research, 26, 1-7.

22. Wernery, U., Juhasz, J., Nagy, P., 2004. Milk yield performance of dromedaries with an automatic bucket milking machine. Journal of Camel Practice and Research, 11, 51-57.

\section{Tables}

Table 1 Descriptive statistics of udder, teat, milk vein morphology and milkability traits 


\begin{tabular}{|lcllll|}
\hline Particulars & Mean \pm S. E. & Minimum & Maximum & S. D. & CV \% \\
\hline Teat length $(\mathrm{mm})$ & & & & & \\
\hline TL-LF & $52.21 \pm 1.66$ & 28.37 & 73.86 & 11.17 & 21.39 \\
\hline TL-LR & $58.52 \pm 2.11$ & 31.52 & 94.74 & 14.18 & 24.23 \\
\hline TL-RF & $50.13 \pm 1.74$ & 26.82 & 82.55 & 11.67 & 23.27 \\
\hline TL-RR & $54.37 \pm 1.82$ & 29.81 & 83.05 & 12.21 & 22.45 \\
\hline Teat diameter (mm) & & & & & \\
\hline TD-LF & $42.44 \pm 1.60$ & 17.27 & 69.26 & 10.74 & 25.30 \\
\hline TD-LR & $46.01 \pm 1.68$ & 22.91 & 74.09 & 11.27 & 24.49 \\
\hline TD-RF & $39.29 \pm 1.31$ & 26.69 & 56.76 & 8.84 & 22.49 \\
\hline TD-RR & $45.20 \pm 1.56$ & 23.54 & 67.25 & 10.49 & 23.20 \\
\hline Udder and milk vein morphology (cm) & & & & \\
\hline Udder depth & $25.44 \pm 0.42$ & 20.57 & 30.98 & 2.84 & 11.16 \\
\hline Udder length & $37.29 \pm 0.80$ & 25.65 & 49.53 & 5.37 & 14.40 \\
\hline Udder height from ground & $114.80 \pm 0.80$ & 101.09 & 124.71 & 5.40 & 4.70 \\
\hline Milk vein diameter & $2.02 \pm 0.08$ & 1.06 & 3.91 & 0.59 & 29.20 \\
\hline Milk vein length & $88.70 \pm 0.96$ & 70.61 & 103.12 & 6.44 & 7.26 \\
\hline Milkability traits & & & & & \\
\hline Milk let down time (s) & $57.15 \pm 1.78$ & 38.54 & 83.90 & 11.99 & 20.97 \\
\hline Morning milk yield (kg) & $2.18 \pm 0.10$ & 0.91 & 3.82 & 0.71 & 32.56 \\
\hline Milking time (min) & $1.78 \pm 0.03$ & 1.30 & 2.18 & 0.21 & 11.79 \\
\hline Milk flow rate (kg/min) & $1.23 \pm 0.04$ & 0.53 & 1.84 & 0.32 & 26.01 \\
\hline
\end{tabular}

TL- Teat length, TD- Teat Daimeter, LF= Left fore, LR= Left rear, RF= Right fore, RR= Right rear,

S.D. = Standard deviation, $\mathrm{CV}=$ Coefficient of variation

Table 2 Least squares means $(\mathrm{mm})$ of teat morphology traits 


\begin{tabular}{|c|c|c|c|c|c|c|c|c|c|}
\hline Particulars & $\mathrm{N}$ & TL-LF & TL-LR & TL-RF & TL-RR & TD-LF & TD-LR & TD-RF & TD-RR \\
\hline Overall Mean & 45 & $49.41 \pm 1.63$ & $56.11 \pm 2.16$ & $47.68 \pm 1.78$ & $53.36 \pm 1.95$ & $40.95 \pm 1.93$ & $44.74 \pm 2.06$ & $37.52 \pm 1.44$ & $44.63 \pm 1.74$ \\
\hline Breed & & * & NS & * & NS & NS & NS & NS & * \\
\hline Bikaneri & 16 & $47.91 \pm 2.41$ & $52.67 \pm 3.19$ & $46.35 \pm 2.64$ & $47.90 \pm 2.89$ & $40.13 \pm 2.85$ & $43.44 \pm 3.05$ & $39.43 \pm 2.13$ & $41.41 \pm 2.58$ \\
\hline Jaisalmeri & 8 & $49.95 \pm 4.03$ & $54.15 \pm 5.34$ & $44.30 \pm 4.42$ & $51.79 \pm 4.84$ & $41.92 \pm 4.77$ & $41.63 \pm 5.11$ & $34.37 \pm 3.57$ & $43.60 \pm 4.32$ \\
\hline Kachchhi & 15 & $56.46 \pm 2.40$ & $63.07 \pm 3.18$ & $54.57 \pm 2.63$ & $58.25 \pm 2.88$ & $44.23 \pm 2.84$ & $50.68 \pm 3.04$ & $42.09 \pm 2.13$ & $51.19 \pm 2.57$ \\
\hline Mewari & 6 & $40.80 \pm 4.16$ & $52.90 \pm 5.52$ & $44.34 \pm 4.56$ & $54.41 \pm 4.99$ & $35.96 \pm 4.92$ & $42.27 \pm 5.27$ & $33.74 \pm 3.69$ & $40.49 \pm 4.45$ \\
\hline Parity & & NS & NS & NS & NS & NS & NS & NS & * \\
\hline First & 10 & $52.40 \pm 4.90$ & $53.84 \pm 6.50$ & $40.89 \pm 5.37$ & $51.59 \pm 5.88$ & $36.85 \pm 5.80$ & $35.13 \pm 6.21$ & $31.28 \pm 4.34$ & $34.81 \pm 5.25$ \\
\hline Second & 12 & $55.38 \pm 3.10$ & $62.97 \pm 4.10$ & $51.35 \pm 3.39$ & $59.83 \pm 3.72$ & $44.19 \pm 3.66$ & $43.51 \pm 3.92$ & $35.79 \pm 2.74$ & $42.80 \pm 3.32$ \\
\hline Third & 14 & $51.86 \pm 3.19$ & $57.96 \pm 4.23$ & $50.71 \pm 3.49$ & $53.89 \pm 3.83$ & $44.42 \pm 3.78$ & $49.36 \pm 4.04$ & $39.31 \pm 2.83$ & $53.62 \pm 3.42$ \\
\hline Fourth & 9 & $40.24 \pm 4.80$ & $50.84 \pm 6.37$ & $46.99 \pm 5.26$ & $49.31 \pm 5.76$ & $38.03 \pm 5.69$ & $48.25 \pm 6.09$ & $41.72 \pm 4.26$ & $44.39 \pm 5.14$ \\
\hline Age at calving & & ** & * & * & NS & * & NS & NS & NS \\
\hline $\begin{array}{l}\text { Breed *parity } \\
\text { Interaction }\end{array}$ & & NS & NS & NS & NS & NS & NS & NS & NS \\
\hline $\mathrm{R}^{2}$ Value & & 0.402 & 0.348 & 0.343 & 0.279 & 0.094 & 0.057 & 0.249 & 0.222 \\
\hline
\end{tabular}

$N=$ Number of animals, ** Highly significant $(p \leq 0.01)$, * Significant $(p \leq 0.05), N S=$ Non-significant, $T L=$ Teat length, TD= Teat diameter, LF= Left fore, LR= Left rear, RF= Right fore and RR=Right rear

Table 3 Least squares means $(\mathrm{cm})$ of udder and milk vein morphology traits

\begin{tabular}{|c|c|c|c|c|c|c|}
\hline Particulars & $\mathrm{N}$ & MVD & MVL & UHG & UD & UL \\
\hline Overall Mean & 45 & $1.91 \pm 09$ & $88.12 \pm 1.01$ & $115.77 \pm 0.95$ & $25.07 \pm 0.05$ & $36.43 \pm 0.88$ \\
\hline Breed & & NS & NS & NS & NS & NS \\
\hline Bikaneri & 16 & $1.80 \pm 0.13$ & $86.52 \pm 1.49$ & $117.03 \pm 21.40$ & $24.55 \pm 0.74$ & $34.81 \pm 1.30$ \\
\hline Jaisalmeri & 8 & $1.81 \pm 0.22$ & $85.96 \pm 2.50$ & $116.23 \pm 2.35$ & $24.93 \pm 1.24$ & $33.37 \pm 2.18$ \\
\hline Kachchhi & 15 & $2.15 \pm 0.13$ & $88.87 \pm 1.49$ & $113.66 \pm 1.40$ & $25.38 \pm 0.73$ & $38.57 \pm 1.30$ \\
\hline Mewari & 6 & $1.81 \pm 0.22$ & $91.59 \pm 2.58$ & $116.70 \pm 2.43$ & $25.34 \pm 1.28$ & $39.29 \pm 2.25$ \\
\hline Parity & & NS & NS & NS & NS & NS \\
\hline First & 10 & $2.04 \pm 0.27$ & $82.95 \pm 3.04$ & $117.49 \pm 2.86$ & $24.87 \pm 1.50$ & $34.90 \pm 2.65$ \\
\hline Second & 12 & $2.38 \pm 0.17$ & $89.47 \pm 1.92$ & $112.08 \pm 1.81$ & $27.06 \pm 0.95$ & $41.07 \pm 1.67$ \\
\hline Third & 14 & $1.88 \pm 0.17$ & $89.01 \pm 1.98$ & $115.43 \pm 1.86$ & $25.65 \pm 0.98$ & $36.38 \pm 1.72$ \\
\hline Fourth & 9 & $1.48 \pm 0.26$ & $90.09 \pm 2.98$ & $117.58 \pm 2.80$ & $23.14 \pm 1.47$ & $34.16 \pm 2.60$ \\
\hline Age at calving & & $\star *$ & NS & NS & * & * \\
\hline Breed *parity Interaction & & NS & NS & NS & NS & NS \\
\hline $\mathrm{R}^{2}$ Value & & 0.360 & 0.306 & 0.130 & 0.127 & 0.244 \\
\hline
\end{tabular}

$\mathrm{N}=$ Number of animals, **Highly significant $(\mathrm{p} \leq 0.01)$, * Significant $(\mathrm{p} \leq 0.05), \mathrm{NS}=$ Non-significant, MVD=Milk vein diameter, MVL=Milk vein length, $\mathrm{UHG}=$ Udder height from ground, UD= Udder depth and UL= Udder length

\section{Table 4 Correlation between udder milk vein and teat morphology traits}




\begin{tabular}{|c|c|c|c|c|c|c|c|c|c|c|c|c|c|}
\hline & TL-LF & TL-LR & TL-RF & TL-RR & TD-LF & TD-LR & TD-RF & TD-RR & MVD & MVL & UHG & UD & UL \\
\hline $\begin{array}{l}\text { TL- } \\
\text { LF }\end{array}$ & 1 & & & & & & & & & & & & \\
\hline $\begin{array}{l}\text { TL- } \\
\text { LR }\end{array}$ & $0.887^{\star \star}$ & 1 & & & & & & & & & & & \\
\hline $\begin{array}{l}\text { TL- } \\
\text { RF }\end{array}$ & $0.881^{\star \star}$ & $0.863^{\star \star}$ & 1 & & & & & & & & & & \\
\hline $\begin{array}{l}\text { TL- } \\
\text { RR }\end{array}$ & $0.787^{\star * *}$ & $0.907 * \star$ & $0.765^{\star \star}$ & 1 & & & & & & & & & \\
\hline $\begin{array}{l}\text { TD- } \\
\text { LF }\end{array}$ & $0.805^{\star \star}$ & 0.700 ** & $0.654^{\star *}$ & $0.598 * \star$ & 1 & & & & & & & & \\
\hline $\begin{array}{l}\text { TD- } \\
\text { LR }\end{array}$ & $0.632^{\star *}$ & $0.634^{\star \star *}$ & $0.604^{\star \star}$ & $0.491^{\star *}$ & $0.695^{\star \star}$ & 1 & & & & & & & \\
\hline $\begin{array}{l}\text { TD- } \\
\text { RF }\end{array}$ & $0.642^{\star *}$ & 0.546 ** & $0.574^{\star \star}$ & $0.421^{* *}$ & $0.663^{\star *}$ & 0.687 ** & 1 & & & & & & \\
\hline $\begin{array}{l}\text { TD- } \\
\text { RR }\end{array}$ & $0.676^{\star \star}$ & $0.628 * \star$ & $0.645^{\star \star}$ & $0.561^{* *}$ & $0.692^{* *}$ & $0.841^{* *}$ & $0.682^{\star \star}$ & 1 & & & & & \\
\hline MVD & $0.800 * \star$ & $0.697 * \star$ & $0.623^{\star \star}$ & $0.654^{\star *}$ & 0.707 ** & $0.404^{\star \star}$ & $0.620 * \star$ & $0.500^{\star *}$ & 1 & & & & \\
\hline MVL & $0.640 * \star$ & $0.705^{\star \star}$ & $0.659 * *$ & $0.633^{\star *}$ & 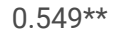 & $0.605^{\star \star}$ & $0.601^{* *}$ & $0.475^{\star \star}$ & 0.514 ** & 1 & & & \\
\hline UHG & $-0.316^{\star}$ & $-0.401^{\star \star}$ & $-0.324^{\star}$ & $-0.326^{\star}$ & $-0.256^{\mathrm{NS}}$ & $\begin{array}{l}0- \\
0.162^{N S}\end{array}$ & $-0.104^{\mathrm{NS}}$ & $-0.101^{\mathrm{NS}}$ & $-0.261^{\mathrm{NS}}$ & $-0.097^{\mathrm{NS}}$ & 1 & & \\
\hline UD & $0.647 * \star$ & $0.660 * *$ & $0.609 * *$ & $0.525^{\star \star}$ & $0.562^{\star \star}$ & $0.455^{\star \star}$ & $0.425^{\star \star}$ & $0.447^{\star *}$ & $0.607 * *$ & $0.599 * *$ & -0.331 * & 1 & \\
\hline UL & $0.624^{\star *}$ & $0.718^{* *}$ & 0.588 ** & $0.715^{\star \star}$ & 0.578 ** & $0.519 * *$ & 0.470 ** & $0.484^{\star \star}$ & 0.644 ** & $0.663^{* *}$ & $-0.222^{\mathrm{NS}}$ & $0.686^{\star \star}$ & 1 \\
\hline
\end{tabular}

, **Highly significant $(\mathrm{p} \leq 0.01)$, * Significant $(\mathrm{p} \leq 0.05), \mathrm{NS}=$ Non-significant, MVD=Milk vein diameter, MVL=Milk vein length, UHG=Udder height from ground, $\mathrm{UD}=$ Udder depth and $\mathrm{UL}=$ Udder length , $T L=$ Teat length, $T D=$ Teat diameter, $L F=$ Left fore, $L R=$ Left rear, $R F=R i g h t$ fore and RR=Right rear

Table 5 Correlation between milkability , teat, udder and milk vein morphology traits

\begin{tabular}{|c|c|c|c|c|}
\hline & MY & MT & MFR & MLDT \\
\hline MY & 1 & & & \\
\hline MT & $0.637 * \star$ & 1 & & \\
\hline MFR & $0.924^{\star \star}$ & $0.308^{*}$ & 1 & \\
\hline MLDT & -0.836 ** & -0.420 ** & $-0.821^{\star \star}$ & 1 \\
\hline TL-LF & $0.692^{\star *}$ & 0.177 & $0.781^{* *}$ & $-0.611^{* \star}$ \\
\hline TL-LR & $0.733^{\star \star}$ & 0.255 & $0.787 * \star$ & $-0.669 * *$ \\
\hline TL-RF & $0.676^{\star \star}$ & $0.212^{\mathrm{NS}}$ & $0.726^{\star *}$ & $-0.649 * \star$ \\
\hline TL-RR & $0.718^{\star \star}$ & $0.296^{*}$ & $0.756^{\star *}$ & -0.650 ** \\
\hline TD-LF & $0.564^{\star *}$ & $0.016^{N S}$ & $0.686^{\star *}$ & $-0.443^{* \star}$ \\
\hline TD-LR & $0.517 * \star$ & $0.149^{N S}$ & $0.563^{\star \star}$ & -0.530 ** \\
\hline TD-RF & $0.410 * *$ & $0.006^{N S}$ & $0.517 * \star$ & $-0.442^{\star \star}$ \\
\hline TD-RR & $0.520 * \star$ & $0.112^{\text {NS }}$ & $0.591^{* *}$ & -0.537 ** \\
\hline MVD & $0.608 * \star$ & $0.132^{N S}$ & $0.711^{\star * *}$ & -0.568 ** \\
\hline MVL & $0.672^{\star \star}$ & $0.266^{N S}$ & $0.688^{* *}$ & $-0.602^{* *}$ \\
\hline UHG & $-0.271^{N S}$ & $-0.065^{N S}$ & $-0.292^{\mathrm{NS}}$ & $0.181^{\mathrm{NS}}$ \\
\hline UD & $0.739 * *$ & $0.368^{\star}$ & $0.719 \star *$ & $-0.635^{\star \star}$ \\
\hline UL & $0.719 * \star$ & $0.386 * \star$ & $0.703^{\star \star}$ & $-0.687 * \star$ \\
\hline
\end{tabular}

Page $9 / 10$ 
, **Highly significant $(\mathrm{p} \leq 0.01)$, Significant $(\mathrm{p} \leq 0.05), \mathrm{NS}=$ Non-significant, MVD=Milk vein diameter, MVL=Milk vein length, UHG=Udder height from ground, UD= Udder depth and UL= Udder length , TL= Teat length, TD= Teat diameter, LF= Left fore, LR= Left rear, RF= Right fore and RR=Right rear, MLDT= Milk let down time, $\mathrm{MT}=$ Milking time, $\mathrm{MY}=$ Milk yield, $\mathrm{MFR}=$ Milk flow rate

\section{Figures}

\section{Figure 1}

Pictorial representation of teat length measurement

R

Figure 2

Pictorial representation of teat diameter measurement

Figure 3

Pictorial representation of udder length measurement

\section{Figure 4}

Pictorial representation of udder depth measurement

\section{Figure 5}

Pictorial representation of udder height from ground measurement

Figure 6

Pictorial representation of milk vein length measurement

局

Figure 7

Pictorial representation of milk vein diameter measurement

\section{Figure 8}

Pictorial representation of milking of camel 